\title{
Vacation Home Rental Concept and Its Connection to Climate Change-A Literature Review
}

\section{Adjnu Damar Ladkoo}

Faculty of Law \& Management, University of Mauritius, Moka, Mauritius

Email: a.ladkoo@uom.ac.mu

How to cite this paper: Ladkoo, A.D. (2016) Vacation Home Rental Concept and Its Connection to Climate Change-A Literature Review. Theoretical Economics Letters, 6, 889896.

http://dx.doi.org/10.4236/tel.2016.65092

Received: July 18, 2016

Accepted: September 9, 2016

Published: September 12, 2016

Copyright $\odot 2016$ by author and Scientific Research Publishing Inc. This work is licensed under the Creative Commons Attribution International License (CC BY 4.0). http://creativecommons.org/licenses/by/4.0/

\begin{abstract}
Gone are the days when tourists had to rely solely on hotels. The new age tourists' accommodation is simply known as vacation home rentals. Companies like Airbnb seem to be taking leaps in the tourism sector with the rapid propagation of their vacation home rental concepts; making hotels fear losing their position on the market. Moreover, with rising issues on climate change, it has become worth understanding how vacation home rental can aid. As such, this study has attempted to understand how vacation home rental companies function, their possible threat to hotels and their contribution to mitigate and adapt to climate changes. This study adopted a qualitative research methodology and used the integrative literature review approach. Climate change is a global phenomenon impelling people to think and act differently so as to have a better future. So, are vacation home rental concepts a boon for the planet and its living entities while being a curse for hotels?
\end{abstract}

\section{Keywords}

Rentals, Hotels, Tourists, Climate, Market

\section{Introduction}

A search about "home rentals" on google search engine as of date, gives as first option, an advert to: "Vacation Home Rentals-The Unique Alternative to Hotels". There has been lately several websites popping up and promoting this new concept of vacation home rentals and some of them as per [1] are: Airbnb, The Apartment Service, At Home Abroad Inc., FlipKey, Holiday Lettings, HomeAway, Homestay.com, iVacationRental, OnlineVacationRentals.com, Rentalo, Sea2Sky Vacation Rentals, TripAdvisor, Tripping, VacationHomeRentals.com, Villas International and VRBO. In just seven years, room letting website Airbnb has become a force to be reckoned with when it comes to holiday accommodation: it has dealt with 40 million guests, has a valuation of over $\$ 20$ billion [2]. This is truly alarming for hotels which are already trying to stand 
firm and progress while facing the never-ending calamity of climate change. With the arrival of vacation home rentals, the situation might worsen. Some marketers of the tourism industry are voicing out their disaccord with this new concept of vacation home rentals. For instance, as per [3] a leading French hoteliers' association has lodged a formal complaint against Airbnb and other online accommodation-rental services, arguing that they compete unfairly in the country. However, proponents of vacation home rentals seem to have a totally different say. They believe that vacation home rentals would be the solution to save a dying tourism sector; for instance, this concept can save countries which might be having most of their hotels in coastal areas or mountain regions, facing calamities such as tsunami and earthquakes. They seem to believe that it is not only a way of not only saving lives but, for enhancing a countries economy. For them, vacation home rentals are part of the adaptation strategies with respect to climate change. Considering the above, the study had as objectives, the following:

- To understand the concept of vacation home rentals.

- To recognise the pros and cons of vacation home rentals.

- To determine vacation home rentals' contribution to mitigate and adapt to climate changes.

\section{Methodology}

The vacation home rental concept has been till date not penned down in research articles. As such, it was clear that an exploratory study would be appropriate. Yet, the question was whether to opt for the positivism (quantitative) or the phenomenological (qualitative) research philosophy. As per [4], Nunkoo and Ramkissoon (2009) critically reported about the different research methodology approaches; where they pointed out that few papers utilized a mixture of both qualitative and quantitative approaches, for instance Andereck et al., 2005; Ap \& Crompton, 1998; Besculides, Lee \& McCormick, 2002; MacKay \& Campbell, 2004; Petrzelka, Krannich, Brehm, \& Trentelelmen, 2005. As such, this study adopted a qualitative approach and used the integrative literature review approach, which as per [5] is a form of research that reviews, critiques, and synthesizes representative literature on a topic in an integrated way. Numerous internet articles, referred journals and other secondary data sources debating on the present topic were consulted. The literature search and compilation was done from April till June 2016. Remarkably, this paper will establish itself by exploring about vacation home rentals via the phenomenological philosophy of research. It is with no doubt that; future enhanced research can be done through quantitative techniques of research. Moreover, the present method adopted can be improved for future studies because as pointed out by [6] an updated integrative review method has the potential to allow for diverse primary research methods to become a greater part of evidence-based practice initiatives.

\section{Literature Review Findings}

\subsection{The Concept of Vacation Home Rentals}

According to [7]: Developing land for residential use appears to be attracting many re- 
gional and national companies and one fast-growing and under-publicized segment of this market, lies in providing the land and homes for recreational and/or investment purposes. For [8]: Motivated home owners are leveraging their largest asset by renting out their homes for short periods of time. These homes include single-family residences commonly located in a residential neighborhood or zoning district. This phenomenon is growing rapidly across the country and presenting policy concerns for state and local governments. The explosion of websites allowing home owners to advertise their residential properties for rent has amplified the short-term rental industry. As per [9]: The short-term rental market has three participants: 1) the host who rents their property, 2) the guest who rents the property on a short-term (e.g., vacation) basis, and 3) the web-based rental platform that serves as a clearing house and rental agency for the hosts and guests. The host may be a property owner, lease holder, or a third party management company that owns or offers individual private rooms or whole houses or apartments. The guests rent out these lodging units based on their needs and preferences, and the rental platform company facilitates the exchange between the hosts and guests and also earns a fee from the hosts for the services rendered. Short-term rentals are a substitute to traditional lodging, offering a new lodging product that includes amenities such as full kitchens, easy access to different neighborhoods, and an opportunity for a more local and familiar experience of the destination. While vacation rentals offer occupant-owners of housing units the opportunity to gain income from renting out spare rooms or secondary units, the industry has also attracted investors who have focused on acquiring and renting out whole residential units, including single-family homes and multifamily units. The web-based rental platforms generate revenue in a variety of ways. AirBnB, the predominant web-based rental platform in Sonoma County, generates revenue by charging hosts a 3 percent commission on each booking and by charging travelers a commission of between 6 and 12 percent, thus generating a yield of anywhere between 9 and 15 percent in commission for every booking. Other vacation rental platforms such as HomeAway and FlipKey offer a pay-per-booking option and also a subscription model, which charges hosts for advertising rentals. The AirBnB website offers three types of rentals: 1) entire homes where the guest has access to the entire unit and the host is generally not present, 2) private rooms where the host is often present in the home, and 3) shared rooms, where hosts or others guests may sleep in the same room. As per [10], most vacation rental websites provide travelers with the information they seek to make a selection. Thus, from a marketers perspective, so as to aid consumers move in the consumer buying process, several important components have to be considered when working on the web-based rental platform and as per [10], they are: a headline, a thumbnail photo, a full description, property photos, a rental rates table, an amenities table, an availability calendar, and guest reviews. Several factors affect the choice of potential and existing consumers and as per [11] rising disposable income, the continuing deterioration of urban centers, and changing lifestyles caused a wider segment of the populace to seek the benefits of resort home living. As rightly pointed out by [12]: The Internet has enabled a more in- 
teractive process and facilitated home exchange kernel which, by the way they are organised, allows a degree of self-organisation. However, considering points above, the webbased rental platforms have to be thoughtfully constructed.

\subsection{Vacation Home Rentals' Pros and Cons}

According to [9]: On the "benefit" side, some say that the short-term rental market can 1) increase tourism and its related economic and fiscal benefits; 2) provide additional income for hosts, particularly those who could not otherwise rent their home or rooms; and 3) extend the economic benefits of tourism (increased sales, etc.) to neighborhoods traditionally not visited. On the "cost" side, the literature indicates that short-term rentals can: 1) shift existing scarce local resident housing to the lodging sector, 2) encourage tenant evictions if a landlord concludes that they can earn more money from short-term rentals than from a long-term tenant, 3) violate local zoning and other ordinances, 4) negatively affect the quality of life in residential areas due to nuisances caused by visitors, and 5) cause loss of household population in given neighborhoods thus reducing the number of school children and residents available for volunteer services such as fire protection.

So as to avoid hassles with vacation home rentals, [10] states that: 1) when starting to rent your vacation home, make sure your second-home business complies with the laws and ordinances of your state, county, and municipality, 2) Before you begin renting, check with county and city officials about the zoning requirements for short-term rental properties. Check the current zoning status of the area in which your vacation home resides and be sure to learn about any proposed changes that may affect it, 3) In addition to your local municipalities, check with the homeowners association about rules regarding vacation rentals within your complex or subdivision, 4) Many areas require vacation rental owners to apply for a business license or permit to rent homes on a short-term basis, 5) In some markets, vacation rental homes have to follow the same basic safety requirements as long-term rentals (e.g., sprinkler systems, fire extinguishers, deadbolt locks, etc.) and may also be required to complete safety inspections. Some areas also have specific rules and regulations around health issues, most commonly involving linen sanitization, well-water testing, and pool and spa maintenance, and 6) sales tax is paid by your guests in addition to your rental rates. You collect the monies and hand them over to the government at a fixed interval (typically quarterly) so, you have to find out the requirements in your area by contacting your county sales tax office.

\subsection{Vacation Home Rental and Climate Changes}

Some of the factors that affect vacation home rentals are: costs which are dependent on the condition of the home to be rented, time of the year, nearness of facilities searched by the clients and equally climate change. It is nowadays obvious that climate and seasons have become more and more unpredictable. Thus, owners or stakeholders involved in the vacation home rental business will have to consider all the above factors 
and cope with them in very thoughtful manners. Adaptation accepts that climate change is likely to occur and attempts to identify steps which may be taken to restrict its adverse consequences and to take advantage of opportunities [13]. Mitigation can be achieved by reducing energy use, for instance through changing travel behaviour, by improving energy efficiency, increasing the use of renewable energy, carbon offsetting strategies, sustainable destination planning and management, tour operators' choice of destinations and packaging of travel products, as well as other changes in business practices [14]. According to [15], mitigation measures range from low-cost initiatives (e.g., using energy-efficient lighting in hotels, monitor energy use) to those that require more effort and investment, for example purchasing more fuel-efficient vehicles, designing a sustainable transport system at a destination, changing transport mode choices or travel patterns. For [5], it becomes clear that a combination of measures is required to reduce the carbon footprint of tourism. Considering the concept of vacation home rentals, interestingly it can be said that it is connected to both adaptation and mitigation strategies. As per [16], continuing to build and buy new hotels, power plants, aeroplanes-locked in the carbon increase for the next 30 to 100 years and to stop this and see $\mathrm{CO} 2$ actually decline, we need to fundamentally alter our behaviours or we will see a six degree increase in global temperature by the end of the century (according to the International Energy Agency). As such, using existing accommodation facilities like those of vacation home rentals would not only aid in reducing the adverse impact of climate change but, will help in the survival of the hotels. The latter can work in close collaboration with home owners who are willing to rent their properties for vacation; whereby services proposed within hotels can be as well transferred to vacation homes. In addition, this would permit customers to benefit from hotel services while being in a private accommodation. However, so as to be economically beneficial, services already catered at hotels, should be exported and no new setting should be created. Thus, stakeholders involved in such new business venture should undergo the economic evaluation process because as rightly pointed out by [17]: a common mistake in presenting costs and benefits is to evaluate the costs for one stakeholder and the benefits for many and the latter further adds that the right type of economic valuation should be used like: the social return on investment (SROI), which values the material costs and benefits to all key stakeholders on a single monetary scale; the cost-effectiveness analysis (CEA), which values the costs of implementing and delivering the Social Impact Bond (SIB), and relates this amount to the total quantity of outcome generated, to produce a "cost per unit of outcome" estimate (e.g. cost per additional individual placed in employment); and the cost-benefit analysis (CBA), which goes further than CEA in placing a monetary value on the changes in outcomes as well (e.g. the value of placing an additional individual in employment). This means that CBA can examine the overall justification for a SIB ("Do the benefits outweigh the costs?"), as well as compare policies which are associated with quite different types of outcome. CBAs quantify as many of the costs and benefits of a SIB as possible, including wider social and environmental impacts (such as crime, air pollution, traffic accidents and so on) where feasible. The 
collaboration between vacation home owners and hotels would be much tallying with the definition of adaptation as per [13]. Simultaneously, vacation home rental owners should be encouraged to convert their properties into green and eco-friendly ones such that energy use can be minimized. Use of natural resources such as solar energy, rain water harvesting, recycling and composting of waste materials can be some of mitigation strategies adopted by vacation home owners. Simultaneously, government can intervene with new policies so as to subsidize the purchase of raw materials for the implementation of the mitigation strategies by the vacation home owners. As per [18]: The pros for going green are as follows: 1) Creating healthy living spaces feels good. You're doing the right thing by creating a healthy environment for the occupant and, you're doing the right thing for the planet; 2) Green design can give your firm a competitive advantage. If you can show people items that are comparable in price and construction to more conventional options, but explain that they're much healthier, they'll almost always take it; 3) It can lead to unexpected opportunities; and 4) Going green is easier than ever. But, the latter also presented some of the disadvantages which are: Potential clients may not believe that green design can be luxurious; 2) Sourcing furniture, fixtures, and materials is more work. Even though options are improving, "the range of choices is narrower, and you're doing more work," to find everything from energy efficient lighting to low-flow faucets to natural upholstery fabrics; and 3) When you can't find what you want, you have to make it yourself. Most importantly therefore is that relevant stakeholders should engage themselves in educating customers so as they can abide and value both the adaptation and mitigation strategies. Here, designing of the web-based platforms have equally high significance in educating the potential or existing customers.

\section{Conclusion}

Vacation home rental concept is a new emerging one, which has both its positive and negative points. While it has permitted many to privately nest them while on vacation, it has equally been highlighted as causing nuisances. However, like any other accommodation concept, it will certainly have its plus or minus points. Concerned authorities and stakeholders should judiciously understand the above, plan and work out polices that would make the positive points of vacation home rentals outweigh the negative ones. One way of viewing this concept would be from the perspective of stakeholders working towards a better, safer and ecofriendly planet. For the latter, vacation home rental concepts would be a means of coping with climate changes. Stakeholders such as marketers who are always striving to satisfy their potential or existing customers would have a key role in promoting this concept and as stated by [19] the challenge of marketers has always been to satisfy the needs and wants of clients in terms of price, packaging, product quality and features, service level amongst others and it was thought-provoking to note from the study that even marketing activities had a role in converting potential customers to genuine consumers of a product. Hence, promotional of the vacation home rental concept should be connected to other emerging concepts such as 
green and social marketing so as to make potential or existing customers view it as strategies for adaptation and mitigation to climate changes. Costs and disadvantages linked to the vacation home rental concepts should be duly addressed like as per [9]: The County adopted a Vacation Rental Ordinance in 2010 that became effective on the first day of 2011; the Ordinance established regulatory requirements including the need to obtain a zoning permit, limits on per room occupancy, controls on nuisance, and subjecting the vacation rentals to the County's 9 percent Transient Occupancy Tax. Teamwork and collaboration between stakeholders is important instead of viewing a new concept as a threat to existing accommodation facilities such as hotels, it should be considered as an aid provided to the planet by alleviating its sufferings due to climatic changes and by preventing more to occur. As per [20] with rising environmental issues such as global warming, the transport industry had to evolve so as to provide greener means of transportation and satisfy demands for eco-friendly technologies. So, why not bring such changes to the accommodation sector of the tourism industry. This research adopted a qualitative approach, which might be perceived as a limitation. However, a research on any new topic is best done by searching and evaluating any possible existent secondary data; which has been equally the case for this study. While some might consider the methodology as a limitation some might view it as a boon to climb the first step in understanding this new rising concept. Still, future studies can be either purely quantitative or have a mixture of qualitative approach as well. Further studies can focus on types of collaboration that can occur between various stakeholders so as to use the vacation home rental concept as an emerging concept to address climatic changes. Also, as per [21] over the last five years, the vacation ownership industry has responded by developing a variety of vacation ownership and access models designed to serve the needs of a broad range of vacation seeking consumers; however, the distinctions between the various models are not clear to most consumers. Thus, new studies can be conducted so as to gather knowledge about this issue. The initial question asked by the author at the very start of the study was whether the vacation home rental concept is a boon for the planet and its living entities while being a curse for hotels. As such, based on the above, it can be concluded that this is certainly a positive element for the planet and equally for the hotels, only if collaboration exists between all connected stakeholders and as well willingness to do business in a sustainable manner.

\section{References}

[1] The Independent Traveler, Inc. (2016) Finding a Vacation Rental. http://www.independenttraveler.com/travel-tips/hotel-and-b-and-b/finding-a-vacation-rental

[2] Hutchison, C. (2015) What Is Airbnb and Why Is It So Controversial? http://www.standard.co.uk/business/what-is-airbnb-and-why-is-it-so-controversial-a29180 61.html

[3] Financial Times, 2016. http://www.ft.com/cms/s/0/6ff2b192-3951-11e6-9a05-82a9b15a8ee7.html\#axzz4DWA07trl

[4] Sawmy, T. and Damar-Ladkoo, A. (2015) Wholesale and Retail E-Commerce in Mauritius: Views of Customers and Employees. Studies in Business and Economics, 10, 170-186. 
[5] Torraco, R.J. (2005) Writing Integrative Literature Reviews: Guidelines and Examples. Human Resource Development Review, 4, 356. http://dx.doi.org/10.1177/1534484305278283

[6] Whitemore, R. (2005) The Integrative Review: Updated Methodology.

[7] Ragatz, R.L. and Gelb, G.M. (1970) The Quiet “Boom” in the Vacation Home Market. California Management Review, 12, 57-64. http://cmr.ucpress.edu/content/12/3/57

[8] Gottlieb, C. (2013) Residential Short-Term Rentals: Should Local Governments Regulate the "Industry"? Planning \& Environmental Law, 65.

http://www.tandfonline.com/doi/pdf/10.1080/15480755.2013.766496

[9] Economic \& Planning Systems, Inc. (2015).

http://www.sonoma-county.org/prmd/docs/vacrent/eps-report-on-impacts-of-vacation-ren tals-on-housing.pdf

[10] Dorsette, K.W. (2009).

https://www.homeaway.com/webdav/site/ha/shared/OC\%20Images/form_widget/HomeAw ay_eBook.pdf

[11] Heinonline, New Ideas in the Vacation Home Market. http://heinonline.org/HOL/LandingPage?handle=hein.journals/stjohn48\&div=70\&id=\&page

[12] Grit, A. and Lynch, P. (2011) An Analysis of the Development of Home Exchange Organisations. http://www.nisconline.com/index.php/rhm/article/view/164

[13] Amelung, B., Blazejczyk, K. and Matzarakis, A. (2007) Climate Change and Tourism- Assessment and Coping Strategies. Maastricht-Warsaw-Freiburg.

[14] Simpson, M.C., Gössling, S., Scott, D., Hall, C.M. and Gladin, E. (2008) Climate Change Adaptation and Mitigation in the Tourism Sector: Frameworks, Tools and Practices. UNEP, University of Oxford, UNWTO, WMO, Paris.

[15] United Nations Environment Programme and World Tourism Organisation (2008) Climate Change and Tourism-Responding to Global Challenges. http://sdt.unwto.org/sites/all/files/docpdf/climate2008.pdf

[16] International Tourism Partnership, 2016. http://tourismpartnership.org/news/climate-change-and-the-hotel-industry/

[17] Centre for Social Impact Bonds, 2016. https://data.gov.uk/sib_knowledge_box/economic-evaluation-costs-benefits-and-maybe-savings

[18] Mckeough, T. (2011) The Pros and Cons of Going Green. http://www.elledecor.com/home-remodeling-renovating/home-renovation/advice/a3426/th e-pros-cons-of-going-green-a-70750/

[19] Damar-Ladkoo, A. (2016) Guerilla Marketing of Fresh Organic Agricultural Products. Theoretical Economics Letters, 6, 246-255.

[20] Barry, M. and Damar-Ladkoo, A. (2016) Consumer Behaviours towards Eco-Cars: A Case of Mauritius. Studies in Business and Economics, 11, 26-44. http://dx.doi.org/10.1515/sbe-2016-0003

[21] Elite Destination Homes, 2015. http://www.elitedestinationhomes.com/wp-content/uploads/2015/02/Vacation-Home-Con cept-Clarifier.pdf 
Submit or recommend next manuscript to SCIRP and we will provide best service for you:

Accepting pre-submission inquiries through Email, Facebook, LinkedIn, Twitter, etc. A wide selection of journals (inclusive of 9 subjects, more than 200 journals)

Providing 24-hour high-quality service

User-friendly online submission system

Fair and swift peer-review system

Efficient typesetting and proofreading procedure

Display of the result of downloads and visits, as well as the number of cited articles

Maximum dissemination of your research work

Submit your manuscript at: http://papersubmission.scirp.org/ 